\title{
Habitat preference of wild boar (Sus scrofa) for feeding in cool-temperate forests
}

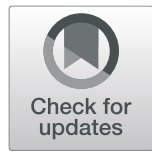

\author{
Youngjin Kim ${ }^{1,2+}$, Soyeon $\mathrm{Cho}^{1 \dagger}$ and Yeonsook Choung ${ }^{1 *}$ (D)
}

\begin{abstract}
Background: The growing wild boar population has become a social issue and its feeding characteristics could affect the physical condition and the plant species composition in the South Korean forests. We aimed to reveal the preference of the wild boar on forest type and site condition as feeding grounds in two cool-temperate forested national parks, Odaesan and Seoraksan, in order to provide information to manage the growing population.

Results: The 75 plots (53.6\%) out of 140 plots were used as feeding grounds by the wild boar, implying a considerably large population. Especially, the observation frequency as feeding ground was the highest in Quercus forests (73.3\%), and it was significantly more preferred than deciduous forest type (44.2\%) and coniferous forest type (32.4\%) $\left(x^{2}=17.591, p<0.001\right)$. Significantly more and deeper pits were found in Quercus forests. Moreover, high elevation and gentle slope ridge were relatively preferred regardless of forest distribution.

Conclusions: South Korean forests are growing qualitatively and quantitatively. Particularly, Quercus forest area has increased markedly, while coniferous forest area has decreased. Since the Quercus forest provides rich food sources for the wild boar, the enlargement of this forest type is expected to increase the wild boar population. The forests located at high elevations have high species diversity, and it is expected that these forests will be greatly affected by the increase in the wild boar population as preferred feeding grounds.
\end{abstract}

Keywords: Diet, Feeding ground, Forest type, Habitat selection, Quercus forest, Rooting

\section{Background}

In South Korea, the population of the wild boar has been growing rapidly since the 2010s (NIBR 2017). The wild boar has damaged the agricultural product since 1970, but it now advances into the urban area and threatens urban living. Consequently, it has become a social issue, and the wild boar is now designated as a big game animal by the Ministry of Environment in South Korea (Ministry of Environment 2010).

The wild boar (Sus scrofa) is a mammal, which is widely distributed throughout the world and has a very wide range of habitats (IUCN 2008). It is distributed in mountainous and hilly areas throughout South Korea (NIBR 2017). It is classified into scrofa, cristatus, leucomystax, and vittatus subspecies groups depending on the size and shape of this species (Wilson

\footnotetext{
* Correspondence: yschoung@kangwon.ac.kr

${ }^{\dagger}$ Youngjin Kim and Soyeon Cho contributed equally to this work.

${ }^{1}$ Department of Biological Sciences, Kangwon National University,

Chuncheon 24341, Republic of Korea

Full list of author information is available at the end of the article
}

and Reeder 2005). The wild boar inhabiting in South Korea belongs to the leucomystax subspecies group. It is large and weighs about $80 \sim 300 \mathrm{~kg}$ (Ministry of Environment 2010).

The wild boar distributes globally because it can eat diverse food types encompassing leaves, roots, seeds, earthworms, insects, and mammals (Baubet et al. 2004; Irizar et al. 2004). Practically, it is an herbivore in that it mainly relies on plants, with a small portion of the animal diet (Baubet et al. 2004; Irizar et al. 2004; Ballari and Barrios-García 2014; Shin 2019).

The increased population size of the wild boar implies that its impact on the natural ecosystem is getting larger. In particular, since the wild boar mainly eats the plant, the larger population consumes more plant materials to maintain the large body size and weight. Consequently, the feeding activities would strongly influence the structure and function of the forested ecosystems (Focardi et al. 2000; Hone 2002). Moreover, boars have a habit of rooting through the forest floor seriously to find food (Lyang and Lee 2010). This causes physical damage to

(c) The Author(s). 2019 Open Access This article is distributed under the terms of the Creative Commons Attribution 4.0 International License (http://creativecommons.org/licenses/by/4.0/), which permits unrestricted use, distribution, and 
the floor as a feeding ground (Singer et al. 1984) and low species diversity (Bratton 1975; Hone 2002).

The feeding characteristics of the wild boar affect not only the physical condition of the forests but also, inevitably, the composition and abundance of plant species (Howe and Bratton 1976; Piroznikow 1998; Cuevas et al. 2010). The effect of the wild boar population on the forest will depend on the type of forest and plant species preferred by wild boars (Virgos 2002). It has been reported that the wild boar prefers certain plant species such as Erythronlum japonicum (Lyang and Lee 2010), suitably humid soil providing high productivity, and deciduous forests producing larger seeds than coniferous forests (Bruinderink and Hazebroek 1996; Welander 2000; Fonseca 2008).

Despite the increasing number of wild boars and the increasing threats of urban living, there is limited information to control them in cool-temperate zones like South Korea. Once the wild boar's preferred site conditions and forest types are known, it would be meaningful information to manage the growing wild boar population. Therefore, this study is aimed at examining the preference of the wild boar on forest type and site condition as feeding grounds in two national parks, Odaesan and Seoraksan, which are cool-temperate forests and known with a large wild boar population in South Korea (NIBR 2017).

\section{Methods}

\section{Study area}

This study was conducted at Odaesan National Park (N37 47'55.12", E128 $32^{\prime} 34.50^{\prime \prime}$ ) and Jeombongsan (N38 02'57.20", E128 25'31.29"), a part of Seoraksan National Park. Odaesan National Park was composed of Quercus forests (58\%), Pinus-Quercus mixed forests (10\%), and other deciduous forests (9\%) (Han et al. 2014), while Quercus mongolica stands were the most dominant forest type in Jeombongsan (KNA 2014). Q. mongolica, among species of genus Quercus, dominated both areas, but $Q$. serrata also occurred at valley-side and foothill areas, and Q. variabilis was found at dry foothill areas.

Odaesan National Park (data from Daegwallyeong weather station) and Jeombongsan (data from Inje weather station) are geographically close to each other, but they show different weather patterns due to the effects of the terrain and the ocean. Annual mean temperatures are 6.6 and $10.1{ }^{\circ} \mathrm{C}$, and annual precipitation is 1898 and $1208 \mathrm{~mm}$ for Odaesan National Park and Jeombongsan, respectively (KMA 2017).

\section{Survey for feeding grounds}

Fourteen regions were selected in order to include a large area and wide variations in site condition such as elevation in Odaesan National Park and Jeombongsan. Afterward, the feeding grounds (hereafter FG) of the wild boar were surveyed (Table 1). One transect per region (1 km in length each) was established from low to high elevation. A total of 140 plots were obtained by installing 10 plots $(20 \mathrm{~m} \times 20 \mathrm{~m})$ per transect with an interval of $100 \mathrm{~m}$. The presence of FG in each plot was determined by the sign of rooting. Rooting was defined as visible signs of soil turnover. The number of pits and the depth of each pit were measured when the sign of rooting was found in a plot. This study only focused on FGs, estimated to be formed from the spring to summer of 2018. It was judged that the plants that emerged this year were either withered or that the soil was not covered with leaves fallen last year. The study was carried out from June to August 2018.

\section{Vegetation and site condition of feeding grounds}

Each plot was classified into one of three forest types: $Q$. mongolica-dominated forest (hereafter Quercus forest), mixed-deciduous forest (hereafter deciduous forest), or coniferous forest. Quercus forest is defined as the forest where the canopy cover of genus Quercus is equal to or larger than $50 \%$. In reality, the canopy layer is dominated with Q. mongolica. In the succession process, the other deciduous forest is the next succession stage of Quercus forest (Lee 2015). Although Q. mongolica is still dominant, it is not mono-stand; other species, such as Tilia amurensis, A. pictum var. mono, Ulmus laciniata, A. pseudosieboldianum, Carpinus cordata, and Maackia amurensis, are mixed. The coniferous forest was mostly pure Pinus densiflora stand, but a few stands were dominated by Abies holophylla, planted Larix kaempferi or Pinus koraiensis. Q. mongolica, Q. variabilis, Q. serrata, or A. pseudosieboldianum commonly occur in the subcanopy layer.

Elevation, slope aspect, slope degree, and topography were measured as site variables. The first three variables were measured and topography was recorded as valleyside, slope, or ridge. Valley-side refers to the lower slope area adjacent to the valley. For analysis, elevation was divided into $\leq 500,500-1000$, and $>1000 \mathrm{~m}$, and slope degree was divided into $15^{\circ}$ intervals. Slope aspect was categorized into $\mathrm{N}\left(315-45^{\circ}\right), \mathrm{E}\left(45-135^{\circ}\right), \mathrm{S}\left(135-225^{\circ}\right)$, and $\mathrm{W}\left(225-315^{\circ}\right)$.

\section{Data analysis}

The preference for forest type and site variables was analyzed by calculating the frequency of FG for each item and performing $X^{2}$ independence analysis. Furthermore, to analyze whether the selection of FGs for forest type is independent of the distribution of forest in each location, we performed the $\chi^{2}$ independence analysis between forest type and four site variables, respectively. We analyzed the significant difference among forest types by Kruskal-Wallis test for both variables. All 
Table 1 Fourteen investigated transects in Jeombongsan and Odaesan

\begin{tabular}{|c|c|c|c|}
\hline Mountain & Transect $^{a}$ & GPS coordinates ${ }^{a}$ & Elevation $(m)^{a}$ \\
\hline \multirow[t]{10}{*}{ Odaesan } & Eulsugol Horyeongbong & N $37^{\circ} 47^{\prime} 20.7^{\prime \prime}$ E $128^{\circ} 30^{\prime} 08.5^{\prime \prime} \sim N 37^{\circ} 47^{\prime} 34.7^{\prime \prime}$ E $128^{\circ} 30^{\prime} 63.1^{\prime \prime}$ & $731 \sim 887$ \\
\hline & Sangwonsa Seodaesa & N $37^{\circ} 47^{\prime} 06.1^{\prime \prime}$ E $128^{\circ} 33^{\prime} 58.6^{\prime \prime} \sim N 37^{\circ} 46^{\prime} 74.4^{\prime \prime}$ E $128^{\circ} 33^{\prime} 39.7^{\prime \prime}$ & $948 \sim 1203$ \\
\hline & Somyeonggol Sangwangbong & N $37^{\circ} 47^{\prime} 63.3^{\prime \prime}$ E $128^{\circ} 33^{\prime} 70.3^{\prime \prime} \sim N 37^{\circ} 48^{\prime} 09.1^{\prime \prime}$ E $128^{\circ} 33^{\prime} 55.1^{\prime \prime}$ & $901 \sim 1108$ \\
\hline & Bukdaesa Sangwangbong & N $37^{\circ} 48^{\prime} 20.1^{\prime \prime}$ E $128^{\circ} 33^{\prime} 87.4^{\prime \prime} \sim N 37^{\circ} 48^{\prime} 50.3^{\prime \prime}$ E $128^{\circ} 33^{\prime} 48.4^{\prime \prime}$ & 1354 1437 \\
\hline & Duroryeong Durobong & N $37^{\circ} 48^{\prime} 66.6^{\prime \prime}$ E $128^{\circ} 34^{\prime} 36.0^{\prime \prime} \sim N 37^{\circ} 49^{\prime} 08.1^{\prime \prime}$ E $128^{\circ} 34^{\prime} 67.9^{\prime \prime}$ & $1320 \sim 1330$ \\
\hline & Jingogae Information Center Noinbong & N $37^{\circ} 46^{\prime} 19.0^{\prime \prime}$ E $128^{\circ} 37^{\prime} 27.3^{\prime \prime} \sim N 37^{\circ} 46^{\prime} 37.1^{\prime \prime}$ E $128^{\circ} 37^{\prime} 79.9^{\prime \prime}$ & $1138 \sim 1258$ \\
\hline & Dongpigol Horyeongbong & N $37^{\circ} 45^{\prime} 98.6^{\prime \prime}$ E $128^{\circ} 34^{\prime} 60.0^{\prime \prime} \sim N 37^{\circ} 46^{\prime} 15.2^{\prime \prime}$ E $128^{\circ} 34^{\prime} 08.0^{\prime \prime}$ & 767 812 \\
\hline & Sogeumgang Ranger Station Yeonhwadam & N $37^{\circ} 48^{\prime} 65.3^{\prime \prime}$ E $128^{\circ} 42^{\prime} 03.0^{\prime \prime} \sim N 37^{\circ} 48^{\prime} 39.0^{\prime \prime}$ E $128^{\circ} 41^{\prime} 57.8^{\prime \prime}$ & $265 \sim 310$ \\
\hline & Bonghwajae Jatgogaegol & N $37^{\circ} 50^{\prime} 51.7^{\prime \prime}$ E $128^{\circ} 42^{\prime} 39.8^{\prime \prime} \sim N 37^{\circ} 50^{\prime} 13.6^{\prime \prime}$ E $128^{\circ} 42^{\prime} 60.5^{\prime \prime}$ & $176 \sim 183$ \\
\hline & Toegokri Deoraengyigol & N $37^{\circ} 50^{\prime} 74.5^{\prime \prime}$ E $128^{\circ} 44^{\prime} 21.2^{\prime \prime} \sim N 37^{\circ} 50^{\prime} 35.7^{\prime \prime}$ E $128^{\circ} 44^{\prime} 39.4^{\prime \prime}$ & $131 \sim 298$ \\
\hline \multirow[t]{4}{*}{ Jeombongsan } & Ganeungol Baekdudaegan & N $37^{\circ} 02^{\prime} 73.8^{\prime \prime}$ E $128^{\circ} 27^{\prime} 62.0^{\prime \prime} \sim N 38^{\circ} 03^{\prime} 06.8^{\prime \prime}$ E $128^{\circ} 27^{\prime} 19.2^{\prime \prime}$ & $790 \sim 846$ \\
\hline & Gangseon Village Gombaeryeong & N $38^{\circ} 01^{\prime} 90.1^{\prime \prime}$ E $128^{\circ} 27^{\prime} 20.0^{\prime \prime} \sim N 38^{\circ} 01^{\prime} 71.5^{\prime \prime}$ E $128^{\circ} 26^{\prime} 72.7^{\prime \prime}$ & $813 \sim 976$ \\
\hline & Danmokryeong Jeombong peak & N $38^{\circ} 03^{\prime} 35.3^{\prime \prime}$ E $128^{\circ} 26^{\prime} 33.8^{\prime \prime} \sim N 38^{\circ} 03^{\prime} 11.8^{\prime \prime}$ E $128^{\circ} 25^{\prime} 82.6^{\prime \prime}$ & $1066 \sim 1262$ \\
\hline & Danmokryeong Bukamryeong & N $38^{\circ} 02^{\prime} 89.1^{\prime \prime}$ E $128^{\circ} 28^{\prime} 59.3^{\prime \prime} \sim N$ 38 $03^{\prime} 20.7^{\prime \prime}$ E $128^{\circ} 29^{\prime} 02.0^{\prime \prime}$ & $781 \sim 877$ \\
\hline
\end{tabular}

${ }^{\mathrm{a}} \mathrm{At}$ each transect, the former and the latter indicate the start and the end point, respectively

analyses were carried out using Statistical Package for Social Science (SPSS) (ver. 23, SPSS 2016).

\section{Results}

\section{Preference for feeding ground by forest type and site condition}

The 140 study plots were composed of 60 Quercus forest stands, 43 deciduous forest stands, and 37 coniferous forest stands. Among them, 75 plots were exploited as FG (53.6\%). The frequency of FG (selected by the wild boar) was significantly different among forest types $\left(\chi^{2}=17.591\right.$, $p<0.001$, Table 2). In addition, it was also significantly different among elevation, slope, and topography classes, respectively $(p<0.05)$, except for the slope aspect classes which was not significant (Table 2).

FG frequency was highest in Quercus forest type (44 plots; $73.3 \%$ ), while those were $44.2 \%$ and $32.4 \%$ in the deciduous forest and coniferous forest, respectively (Fig. 1). The frequency of FG was higher at a higher elevation (Fig. 2). In particular, that of FG was $81 \%$ when plots were located above $1000 \mathrm{~m}$. Moreover, it tended to increase with a gentler slope, so it was $82.6 \%$ when the slope was equal to or less than $15^{\circ}$. The FG frequency in

Table $2 x^{2}$ independence analysis for the feeding ground preference according to forest type and site condition

\begin{tabular}{lll}
\hline Source & $x^{2}$ & $p$ value \\
\hline Forest type & 17.591 & $<0.001$ \\
Elevation & 32.301 & $<0.001$ \\
Slope degree & 22.978 & $<0.001$ \\
Micro-topography & 6.823 & $<0.05$ \\
Slope aspect & 5.074 & $\mathrm{~ns}^{\mathrm{a}}$ \\
\hline
\end{tabular}

${ }^{a}$ Not significant the ridge was as high as $72.2 \%$. On the other hand, the FG frequency on the north aspect was higher than those on other aspects although it was not significantly different by slope aspect classes (Table 2).

In addition, we analyzed if the preference of the wild boar on the forest type and site condition was independent to or affected by the distribution of a specific forest type (Table 3). The selection of forest type and elevation was found to be independent $\left(\chi^{2}=51.552, p<0.001\right)$. The three forest types were distributed at different altitudinal ranges. In other words, Quercus forest, deciduous forest, and coniferous forest types tended to distribute at high, intermediate, and low elevation areas, respectively. Contrary to this, the frequency of FG

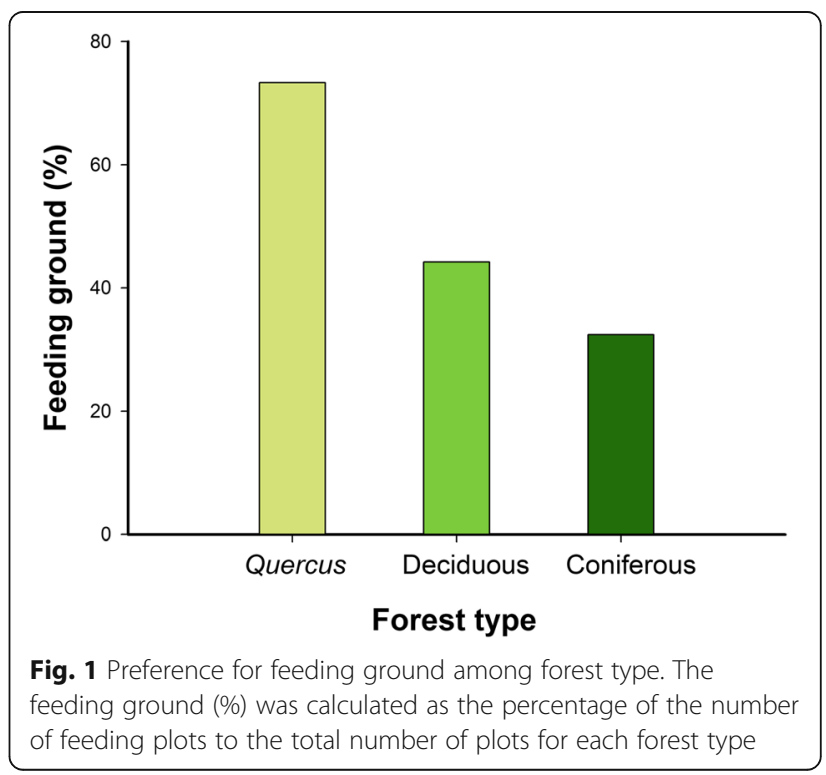



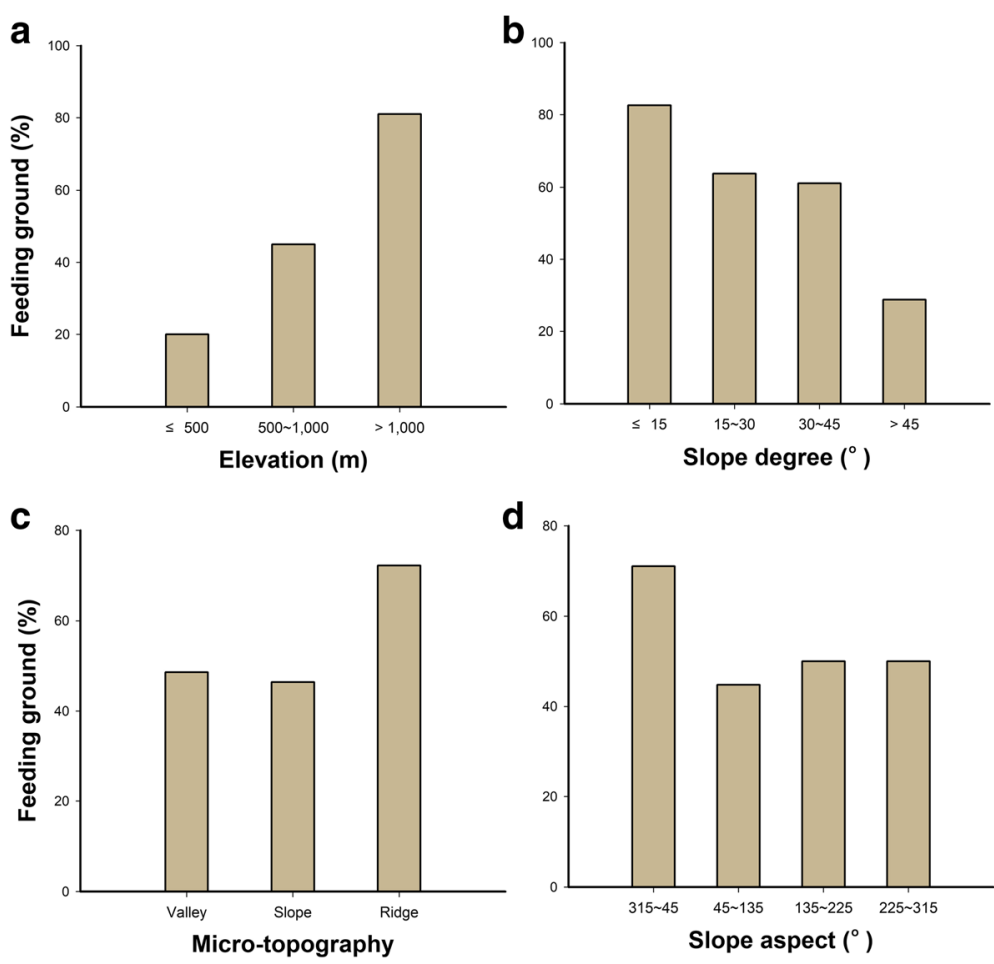

Fig. 2 Preference for feeding ground according to a elevation, b slope degree, c micro-topography, and $\mathbf{d}$ slope aspect. The feeding ground (\%) was calculated as the percentage of the number of feeding plots to the total number of plots for each class of the four site variables

increased with a higher elevation for all three forest types including coniferous forests which were mainly distributed at lower altitudes.

The selection of forest type and slope degree was found to be independent $\left(\chi^{2}=22.397, p<0.001\right.$, Table 3). Quercus forest type was mainly found on slopes below $30^{\circ}$, while deciduous forest type and coniferous forest type mostly distributed on steep slopes ( $\geq 45$ degrees). Nevertheless, the FG frequency showed an opposite pattern, the highest on the gentle slope. Especially, the absolute FG frequency of the Quercus forests on a gentle slope $(\leq 15$ degrees) was $91 \%$. In the deciduous forest and coniferous forest types, FG frequency was higher on a gentle slope, compared to the distribution of actual stands.

The selection of forest type and micro-topography was also found to be independent $\left(\chi^{2}=20.299, p<0.001\right.$, Table 3). Quercus forest was distributed on slope and ridge at a similar frequency. The deciduous forest was found most often at the valley-side, and the coniferous forest was most abundantly distributed on a slope area. In the Quercus forest, the frequency of FG was similar regardless of the topography type (except for the valleyside, which had a small number of sample plots). In the deciduous forest and coniferous forest, the FG frequency was higher on the ridge compared to the plot distribution. As a result, the frequency of FG was the highest on the ridge. Even though the FG frequency was relatively high on the north aspect in three forest types, it was not significantly different (Table 3 ).

\section{Pattern of feeding grounds}

Among all FGs $(n=75)$, the median number of pits per plot was 12.0 (ranging between 1 and 54) (Fig. 3). It was significantly different among forest types $\left(\chi^{2}=9.739, p<0.01\right)$. There were 19.0 pits per plot in the Quercus forest, while 6.0 and 5.0 pits per plot in the deciduous and coniferous forests, respectively.

The overall median pit depth was $8.7 \mathrm{~cm}$ (ranging between 2 and $22 \mathrm{~cm}$ ) (Fig. 3). It was also significantly different among forest types $\left(\chi^{2}=7.811, p<0.05\right)$. Median pit depth was the deepest in the Quercus forest (10.8 $\mathrm{cm})$, followed by the deciduous forest $(7.3 \mathrm{~cm})$ and the coniferous forest $(6.5 \mathrm{~cm})$. It has been reported that the mean pit depth of wild boar was $10.7 \mathrm{~cm}$ in Spain and $5 \sim 15 \mathrm{~cm}$ in California, USA, which agreed with the results of this study (Kotanen 1995; Bueno et al. 2013).

\section{Discussion}

\section{Food source of wild boar}

The energy demand, the type and amount of food resources, the seasonal resource availability, and the safe sites affect the FG selection of the wild boar (Abaigar et al. 1994; Welander 2000; Cahill et al. 2003; Baubet et al. 2004; Ballari and Barrios-García 
Table 3 Relative frequencies of plots and feeding grounds according to forest type and site variables

\begin{tabular}{|c|c|c|c|c|c|c|c|c|}
\hline \multirow[t]{2}{*}{ Site } & \multicolumn{2}{|c|}{ Quercus forest } & \multicolumn{2}{|c|}{ Deciduous forest } & \multicolumn{2}{|c|}{ Coniferous forest } & \multicolumn{2}{|l|}{ Total } \\
\hline & Plot (\%) & Feeding ground (\%) & Plot (\%) & Feeding ground (\%) & Plot (\%) & Feeding ground (\%) & Plot (\%) & Feeding ground (\%) \\
\hline Elevation (m) & \multicolumn{8}{|c|}{$x^{2}=51.552^{a}, p$ value $<0.001$} \\
\hline$<500$ & - & - & 4.7 & 0.0 & 75.7 & 12.0 & 21.4 & 13.7 \\
\hline $500 \sim 1000$ & 35.0 & 29.2 & 65.1 & 50.1 & 18.9 & 32.0 & 40.0 & 30.6 \\
\hline$>1000$ & 65.1 & 70.8 & 30.2 & 49.9 & 5.4 & 56.0 & 38.6 & 55.8 \\
\hline Total & 100.0 & 100.0 & 100.0 & 100.0 & 100.0 & 100.0 & 100.0 & 100.0 \\
\hline Slope degree $\left(^{\circ}\right)$ & \multicolumn{8}{|c|}{$x^{2}=22.397^{\mathrm{a}}, p$ value $<0.001$} \\
\hline$<15$ & 18.3 & 32.3 & 16.3 & 41.8 & 13.5 & 33.8 & 16.4 & 34.9 \\
\hline $15 \sim 30$ & 43.3 & 30.0 & 27.9 & 24.4 & 24.3 & 9.4 & 33.6 & 27.0 \\
\hline $30 \sim 45$ & 18.3 & 25.8 & 7.0 & 27.9 & 10.8 & 21.1 & 12.9 & 25.9 \\
\hline$>45$ & 20.0 & 11.8 & 48.8 & 6.0 & 51.4 & 35.6 & 37.1 & 12.2 \\
\hline Total & 100.0 & 100.0 & 100.0 & 100.0 & 100.0 & 100.0 & 100.0 & 100.0 \\
\hline Micro-topography & \multicolumn{8}{|c|}{$x^{2}=20.299^{a}, p$ value $<0.001$} \\
\hline Valley-side & 5.0 & 41.0 & 51.2 & 26.7 & 27.0 & 39.0 & 25.0 & 29.1 \\
\hline Slope & 48.3 & 29.7 & 37.2 & 14.7 & 64.9 & 28.5 & 49.3 & 27.7 \\
\hline Ridge & 46.7 & 29.3 & 11.6 & 58.7 & 8.1 & 32.5 & 25.7 & 43.2 \\
\hline Total & 100.0 & 100.0 & 100.0 & 100.0 & 100.0 & 100.0 & 100.0 & 100.0 \\
\hline Slope aspect $\left(^{\circ}\right)$ & \multicolumn{8}{|c|}{$x^{2}=4.185^{a}, p$ value $n s^{b}$} \\
\hline $315 \sim 45$ & 20.0 & 30.6 & 25.6 & 35.6 & 21.6 & 32.5 & 22.1 & 32.9 \\
\hline $45 \sim 135$ & 18.3 & 18.2 & 30.2 & 17.2 & 13.5 & 38.9 & 20.7 & 20.8 \\
\hline $135 \sim 225$ & 38.3 & 20.3 & 27.9 & 23.3 & 29.7 & 23.6 & 32.9 & 23.2 \\
\hline $225 \sim 315$ & 23.3 & 31.0 & 16.3 & 24.0 & 35.1 & 5.0 & 24.3 & 23.2 \\
\hline Total & 100.0 & 100.0 & 100.0 & 100.0 & 100.0 & 100.0 & 100.0 & 100.0 \\
\hline
\end{tabular}

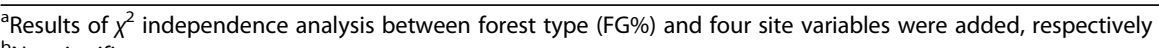

${ }^{\mathrm{b}}$ Not significant

2014; Gallo Orsi et al. 2014; Lee 2014). Bueno et al. (2009) argued that food is the most important factor for the wild boar to choose FG, followed by elevation, slope, the distance from a water system, and the distance from humans.

The wild boar mainly eats vegetable matter such as roots and fleshy fruits from spring to summer, forest fruits (e.g., acorns, chestnuts, and beechnuts) during autumn, and roots during the winter (Genov 1981; Dardaillon 1986; Taylor and Uvalde 1999; Schley and Roper 2003). Baubet et al. (2004) found that $91 \%$ of the food sources of the wild boar were the plant and $1 \%$ of them were the animal when the feces of the wild boar and gastric contents were analyzed in forests in southeastern
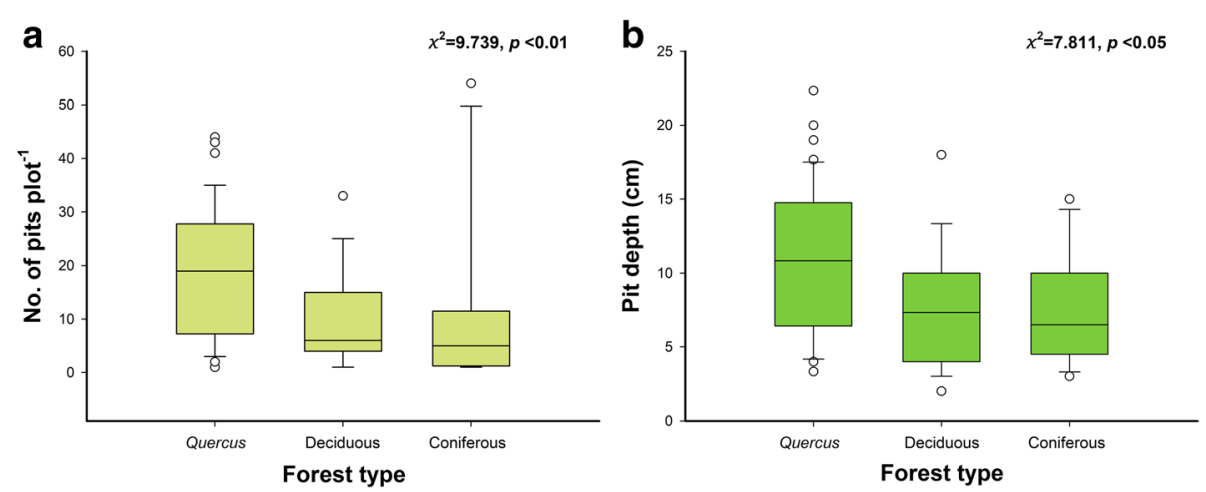

Fig. 3 Comparison of the rooting pattern among forest types: a number of pits per plot and $\mathbf{b}$ pit depth at feeding grounds 
France. The plant root (39\%) was the most common food source. Similarly to this, Irizar et al. (2004) found that $94 \%$ of the diet were also plant-origin food based on the gastric contents of the wild boar in the forests of northern Spain. Since the study was conducted from autumn to winter, acorns and chestnuts accounted for $85 \%$ of food. Shin (2019) analyzed the food sources of the wild boar at Jeombongsan, South Korea, and found that $61 \%$ of food sources was plantorigin from the feces mainly made from summer. The wild boar consumed Rosaceae the most followed by bryophyte and Fagaceae.

\section{Quercus forest preference of wild boar}

Wild boars selectively preferred the Quercus forest as FG, and they dug pit the most and deepest in this forest. Acorns, in particular, are the most important food resource for wild animals such as wild boars (Welander 2000; Fonseca 2008; Shin 2019) and the Asiatic black bear (SRTI 2012). It is a stable food source of supply due to the large area of Quercus-dominated forests. Singer et al. (1981) found that in mast year when acorn production is high, the wild boar's home range has expanded 3 to 5 times compared to the failure year. The mean acorn production of Odaesan and Seoraksan National Park were and $46.7(\max 164.1)$ and $17.3(\max 94.7) \mathrm{g} \mathrm{m}^{-2}$ in 2018, respectively (Choung et al. 2018). That of Jirisan National Park peaked in 2009 reached $77.7 \mathrm{~g} \mathrm{~m}^{-2}$ (SRTI 2012).

In addition, considering that the traces of FG found in this study were made from spring to summer, it may be the result of consuming favorite food sources as well as acorns. For example, the wild boar particularly likes the bulbs of E. japonicum and Lilium and the fruits of Rosaceae (Lyang and Lee 2010; Shin 2019). Therefore, large-scale excavation is commonly found in the Quercus forest where these species occur (Choung and Lee 2019). These species are more common in the Quercus forest (Choung and Lee 2019). The bulb of E. japonicum is buried about $12 \mathrm{~cm}$ below the ground surface (Lyang and Lee 2010), and it could be the reason why the wild boar dug deeper in the Quercus forest type than other forest types. The wild boar digs even Sasa borealis stands in the Quercus forest, which is dominated by S. borealis and has very low species diversity (Cho et al. 2018a, $2018 \mathrm{~b})$. The food sources such as acorns and insects for the wild boar are presumably between the packed roots or dense culms of $S$. borealis.

The wild boar less preferred other deciduous forest and coniferous forest types, mainly dominated by $P$. densiflora, because these forest types provide different food sources and they are located at relatively low elevations or at the bottom of steep mountains.

\section{Site preference of wild boar}

The results showed that the wild boar preferred ridge areas with a high altitude and a gentle slope. It was also analyzed that the site condition was associated with the distribution of the forest type to some extent. While Quercus forests tended to distribute at high elevations, deciduous forests and coniferous forests were mainly found at middle and low elevations, respectively. Nonetheless, the independence analysis confirmed that FG was selected independently between forest type and site variables except for slope aspect.

The wild boar showed feeding activities mostly at higher altitude because these areas had rich potential food sources due to maybe the high plant diversity (Choung and Lee 2019), and moreover they were safe sites due to access difficulty. Park and Lee (2003) reported that the wild boar preferred habitats far from forest roads that were frequently visited by a number of hikers. Similarly, Virgos (2002) suggested that the wild boar preferred large forest patches because they could avoid people and these patches had diverse food sources.

The ridge areas are drier and have fewer food resources than slope and valley-side areas in general. So it was known for the wild boar to prefer moist sites that are easy to dig (Vittoz and Hainard 2002). Nevertheless, the wild boar prefers the ridge relatively more than other topography probably because it secures a clearer view due to relatively less dense vegetation and provides a pathway to a higher elevation in an emergency situation. The ridge is the major corridor for wild animals (Lee et al. 2011; Woo 2014; Kim et al. 2018).

\section{Expansion of Quercus forest and projection of wild boar population}

It is highly likely that the size of the wild boar population will continue to increase. The NIBR (2017) has conducted a long-term monitoring on the wildlife of South Korea and reported that the wild boar inhabited mountainous areas throughout the country and the population size has increased since the 2010s. The estimated number of the wild boar in Inje, Pyeongchang, and Hongcheon areas including the study area was reported as 7.2 per $100 \mathrm{ha}^{-1}$ as of 2017, which was higher than the nationwide mean number (5.6).

Furthermore, the area and wood stock of the Quercus forest is rapidly increasing replacing the pioneer coniferous forest (KFRI 2010; Lee 2010). These changes mean the increase of the food sources and the potential refuge sites, resulting in the expansion of the potential carrying capacity for the wild boar. The home range of the wild boar was $1.5 \mathrm{~km}^{2}$ on average in many national parks and the core feeding area is far smaller $\left(0.3 \mathrm{~km}^{2}\right)$ (Choi et al. 2006; KNPRI 2013, 2017). 
Moreover, wild boars have the habit of rooting in a habitat for several months (KNPRI 2016). Also, the home range has expanded 3 to 5 times in a mast year (Singer et al. 1981). This feeding behavior could lead to a reduction in plant species richness and the diversity of Quercus forests with high species diversity at high elevations (Ickes et al. 2001; Siemann et al. 2009). High elevation regions are more vulnerable to change (Adhikari et al. 2018). Because of this, we are concerned that the increase in wild boar populations will have a greater impact on forests, especially Quercus forest.

\section{Conclusion}

The feeding characteristics of the wild boar were examined in ten regions of cool-temperate Odaesan and Seoraksan National Parks. The results showed that $53.6 \%$ of the 140 plots were dug and used as a FG, implying that there is a considerably large wild boar population. Particularly, the frequency of FG was the highest in Quercus forests (73.3\%). The results showed that the wild boar preferred Quercus forest to deciduous forests (44.2\%) and coniferous forests (32.4\%). In addition, the boar favored ridge areas at high elevations and with a gentle slope, independent to the distribution of forest type. This study confirmed that Quercus forests growing on ridges at high elevations were the most FG preferred by the wild boar.

Forests in South Korea are rapidly developing qualitatively and quantitatively. Quercus forest area has increased noticeably, replacing coniferous forest area. Since Quercus forests provide major food sources for wild boars, an increase of this forest type will lead to an increase in the size of the wild boar population. In South Korea, forests located at a high altitude have relatively high species diversity due to past disturbances of lowland forests. Therefore, it is expected that the increase in the wild boar population size will affect these forests greatly as preferred FGs.

\section{Abbreviations}

IUCN: International Union for Conservation of Nature and Nature Resources: KFRI: Korea Forest Research Institute; KMA: Korea Meteorological Administration; KNA: Korea National Arboretum; KNPRI: Korea National Park Research Institute; NIBR: National Institute of Biological Resources; SPSS: Statistical Package for Social Science; SRTI: Species Restoration Technology Institute

\section{Acknowledgements}

We would like to thank Jaegwan Kim, Jaesang Noh, and Jongseong Lee who helped with the fieldwork.

\section{Authors' contributions}

YK and SC conducted field investigation, analyzed the data, and wrote the manuscript draft. YC planned, wrote, and revised the manuscript. All the authors approved the final manuscript.

\section{Funding}

This study was supported by the Basic Science Research Program through the National Research Foundation of Korea (NRF) funded by the Ministry of
Education (NRF-2017R1D1A2B04032004), Ministry of Environment, and National Institute of Ecology as the National Long-Term Ecological Research Project (NIE-Strategy Research-2018-02) and a 2017 research grant from Kangwon National University (520170490).

\section{Availability of data and materials}

The datasets during and/or analyzed during the current study are available from the corresponding author on reasonable request.

Ethics approval and consent to participate

Not applicable

\section{Consent for publication}

Not applicable

\section{Competing interests}

The authors declare that they have no competing interests.

\section{Author details}

'Department of Biological Sciences, Kangwon National University, Chuncheon 24341, Republic of Korea. ${ }^{2}$ Present Address: Migang Ecology Institute, Anyang 14057, Republic of Korea.

Received: 17 April 2019 Accepted: 16 July 2019

Published online: 06 August 2019

\section{References}

Abaigar T, Del Barrio G, Vericad J. Habitat preference of wild boar (Sus scrofa L, 1758) in a Mediterranean environment. Indirect evaluation by signs. Mammalia. 1994:58:201-10.

Adhikari P, Shin M, Jeon J, Kim HW, Hong S, Seo C. Potential impact of climate change on the species richness of subalpine plant species in the mountain national parks of South Korea. J Ecol Environ. 2018;42:36.

Ballari SA, Barrios-García MN. A review of wild boar Sus scrofa diet and factors affecting food selection in native and introduced ranges. Mammal Rev. 2014; 44:124-34.

Baubet E, Bonenfant C, Brandt S. Diet of the wild boar in the French Alps. Galemys. 2004;16:101-13.

Bratton SP. The effect of the European wild boar, Sus scrofa, on gray beech forest in the Great Smoky Mountains. Ecology. 1975;56:1356-66.

Bruinderink GG, Hazebroek E. Wild boar (Sus scrofa scrofa L.) rooting and forest regeneration on podzolic soils in the Netherlands. For Ecol Manag. 1996;88: 71-80.

Bueno CG, Alados CL, Gómez-García D, Barrio IC, García-González R. Understanding the main factors in the extent and distribution of wild boar rooting on alpine grasslands. J Zool. 2009;279:195-202.

Bueno CG, Azorín J, Gómez-García D, Alados CL, Badía D. Occurrence and intensity of wild boar disturbances, effects on the physical and chemical soil properties of alpine grasslands. Plant Soil. 2013;373:243-56.

Cahill S, Llimona F, Gràcia J. Spacing and nocturnal activity of wild boar Sus scrofa in a Mediterranean metropolitan park. Wild Biol. 2003:9:3-13.

Cho S, Kim Y, Choung Y. Distribution and synchronized massive flowering of Sasa borealis in the forests of Korean National Parks. J Ecol Environ. 2018a;42:37.

Cho S, Lee K, Choung Y. Distribution, abundance, and effect on plant species diversity of Sasa borealis in Korean forests. J Ecol Environ. 2018b;42:9.

Choi T, Lee Y, Park C. Home-range of wild boar, Sus scrofa living in the Jirisan National Park, Korea. J Ecol Field Biol. 2006;29:253-7 (in Korean).

Choung Y, Kim Y, Noh J, Cho S, Lee J. Acorn production in Seoraksan and Odaesan National Park. In: KNPRI, editor. Influence of the Asiatic black bear on the forests in Korea. Wonju: KNPRl; 2018. (in Korean).

Choung Y, Lee K. Species ecology of central Korean forest. Seoul: Nature and Ecology; 2019. (in Korean)

Cuevas MF, Novillo A, Campos C, Dacar MA, Ojeda RA. Food habits and impact of rooting behavior of the invasive wild boar, Sus scrofa, in a protected area of the Monte Desert, Argentina. J Arid Environ. 2010;74:1582-5.

Dardaillon M. Seasonal variation in habitat selection and spatial distribution of wild boar (Sus scrofa) in the Camargue, Southern France. Behav Process. 1986;13:251-68.

Focardi S, Capizzi D, Monetti D. Competition for acorns among wild boar (Sus scrofa) and small mammals in a Mediterranean woodland. J Zool. 2000;250:329-34. 
Fonseca C. Winter habitat selection by wild boar Sus scrofa in southeastern Poland. Eur J Wildl Res. 2008;54:361-6.

Gallo Orsi U, Sicuro B, Durio P, Canalis L, Mazzoni G, Serzotti E, Chiariglione D. Where and when: the ecological parameters affecting wild boars choice while rooting in grasslands in an alpine valley. J Mountain Ecol. 2014;3:160-4.

Genov P. Food composition of wild boar in north-eastern and western Poland. Acta Theriol. 1981;10:185-205.

Han B, Lee K, Choi J, Yeum J. Characteristics of vegetation distribution according to the growth environment of Odaesan (Mt.) National Park. Pro Korean Soc Environ Ecol Con. 2014;24:21-2 (in Korean).

Hone J. Feral pigs in Namadgi National Park, Australia: dynamics, impacts and management. Biol Conserv. 2002;105:231-42.

Howe TD, Bratton SP. Winter rooting activity of the European wild boar in the Great Smoky Mountains National Park. Castanea. 1976;41:256-64.

Ickes K, Dewalt SJ, Appanah S. Effects of native pigs (Sus scrofa) on woody understorey vegetation in a Malaysian lowland rain forest. J Trop Ecol. 2001;17:191-206.

Irizar I, Laskurain NA, Herrero J. Wild boar frugivory in the Atlantic Basque Country. Galemys. 2004;16:125-33.

IUCN. The IUCN red list of threatened species: Sus scrofa. UK: IUCN; 2008 KFRI. Forest eco-atlas of Korea. Seoul: Korea Forest Research Institute; 2010.

Kim J, Lee S, Yoon J, Park S, Lim S, Choi W, Hwang K, Yoon Y. Evaluation of habitat of endangered species of musk deer using matrix method. Proc Korean Soc Environ Ecol Con. 2018;28:112 (in Korean).

KMA. Annual climatological report. Seoul: Korea Meteorological Administration; 2017. in Korean

KNA. Geography and vegetation of Mt. Jumbong experimental forest. Pocheon: Korea National Arboretum; 2014. in Korean

KNPRI. Ecology of wild boar in Hallyeohaesang and Odaesan National Park. Namwon: Korea Forest Research Institute; 2013. (in Korean)

KNPRI. A survey of the distribution of Sus scrofa in urban national parks. Korea National Park Research Institute: Wonju; 2016. (in Korean)

KNPRI. Management plan of wild boar in Bukhansan National Park. Wonju: Korea Forest Research Institute; 2017. (in Korean)

Kotanen PM. Responses of vegetation to a changing regime of disturbance: effects of feral pigs in a Californian coastal prairie. Ecography. 1995;18:190-9.

Lee AN. GIS analysis of habitat characteristics of Artiodactyla mammals in the Beakdudaegan mountains. Chuncheon: Kangwon National University; 2014. (in Korean)

Lee B, Cho J, Lim S, Kim Y, Kwon G, Lee AN. A survey of the distribution of endangered goral (Naemohedus caudatus) in Odaesan National Park. Pro Kor Soc Env Eco Con. 2011;21:65-8 (in Korean).

Lee DK. Korean forests. Seoul: Korea Forest Research Institute; 2010. (in Korean)

Lee K. Classification of forested vegetation and successional development in the central-eastern Korean Peninsula. Chuncheon: Kangwon National University; 2015. (in Korean)

Lyang D, Lee K. Responses of an herbaceous community to wild boar (Sus scrofa coreanus Heude) disturbance in a Quercus mongolica forest at Mt. Jeombong, Korea. J Ecol Environ. 2010;33:205-16.

Ministry of Environment. Harmful wild boar management plan. Incheon: Ministry of Environment; 2010. (in Korean)

NIBR. 2017 wildlife survey. Incheon: Korea Institute of Biological Resources; 2017. (in Korean)

Park C, Lee W. Development of a GIS-based habitat suitability model for wild boar Sus scrofa in the Mt. Baekwoonsan region, Korea. Mammal Study. 2003;28:17-21.

Piroznikow $E$. The influence of natural and experimental disturbances on emergence and survival of seedlings in an oak-linden-hornbeam (TilioCarpinetum) forest. Pol J Ecol. 1998;46:137-56.

Schley L, Roper T. Diet of wild boar Sus scrofa in Western Europe, with particular reference to consumption of agricultural crops. Mammal Rev. 2003:33:43-56.

Shin HM. Diet compositions of Korean wild boar (Sus scrofa coreanus) at Mt. Jeombong using non-invasive molecular analysis. Suwon: Ajou University; 2019.

Siemann E, Carrillo JA, Gabler CA, Zipp R, Rogers WE. Experimental test of the impacts of feral hogs on forest dynamics and processes in the southeastern US. For Ecol Manag. 2009;258:546-53.

Singer FJ, Otto DK, Tipton AR, Hable CP. Home ranges, movements, and habitat use of European wild boar in Tennessee. J Wildl Manag. 1981;45:343-53.

Singer FJ, Swank WT, Clebsch EEC. Effects of wild pig rooting in a deciduous forest. J Wildl Manag. 1984;48:464-73.

SPSS. IBM SPSS statistics for windows, version 23.0. Armonk: IBM Corp; 2016.

SRTI. Annual report (2009-2011). Gurye: Species Restoration Technology Institute; 2012. (in Korean)
Taylor RB, Uvalde TX. Seasonal diets and food habits of feral swine. In: Texas Animal Health Commission, editor. Proceedings of the 1999 National Feral Swine Symposium. USA: Texas Animal Health Commission; 1999. p. 58-66.

Virgos E. Factors affecting wild boar (Sus scrofa) occurrence in highly fragmented Mediterranean landscapes. Can J Zool. 2002;80:430-5.

Vittoz P, Hainard P. Impact of free-range pigs on mountain pastures in the Swiss Jura. Appl Veg Sci. 2002;5:247-54.

Welander J. Spatial and temporal dynamics of wild boar (Sus scrofa) rooting in a mosaic landscape. J Zool. 2000;252:263-71.

Wilson DE, Reeder DM. Mammal species of the world: a taxonomic and geographic reference. Baltimore: JHU Press; 2005.

Woo D. A study on ecological characteristics and conservation of yellow-throated marten (Martes flavigula) in temperate forests of Korea. Seoul: Seoul National University; 2014. (in Korean)

\section{Publisher's Note}

Springer Nature remains neutral with regard to jurisdictional claims in published maps and institutional affiliations.
Ready to submit your research? Choose BMC and benefit from:

- fast, convenient online submission

- thorough peer review by experienced researchers in your field

- rapid publication on acceptance

- support for research data, including large and complex data types

- gold Open Access which fosters wider collaboration and increased citations

- maximum visibility for your research: over $100 \mathrm{M}$ website views per year

At BMC, research is always in progress.

Learn more biomedcentral.com/submissions 